\title{
Tradisi Jamasan Pusaka Di Desa Baosan Kidul Kabupaten Ponorogo (Kajian Nilai Budaya Dan Sumber Pembelajaran Sejarah
}

\author{
Kabul Priambadi ${ }^{1}$ dan Abraham Nurcahyo ${ }^{2}$ \\ ${ }^{1}$ Alumni Program Studi Pendidikan Sejarah, FKIP, Universitas PGRI Madiun \\ ${ }^{2}$ Dosen Program Studi Pendidikan Sejarah, FKIP, Universitas PGRI Madiun
}

\begin{abstract}
Abstrak
Tradisi dapat ditunjukkan dari hasil budaya yang masih ditemui, baik yang sederhana maupun modern. Hal ini merupakan kemajuan pola pikir nenek moyang kita dalam berkarya baik secara fisik maupun non fisik. Sebagai hasil teknologi, kebudayaan fisik cepat mengalami perkembangan. Kebudayaan sendiri merupakan kumpulan pengetahuan yang secara sosial diwariskan dari generasi berikutnya yang memiliki kelemahan dan keunggulan, oleh karena itu, tidak ada kebudayaan yang sempurna. Jamasan pusaka merupakan salah satu cara merawat benda-benda pusaka seperti keris yang di angggap memiliki tuah. Dalam tradisi masyarakat jawa, jamasan pusaka menjadi sesuatu kegiatan spiritual yang cukup sakral dan dilakukan hanya dalam waktu tertentu saja yaitu di bulan suro seperti yang dilakukan di Desa Baosan Kidul Kabupaten Ponorogo. Dalam penelitian ini bertujuan untuk mendekatkan generasi muda dengan tradisi yang masih ada di dalam lingkungannya, supaya generasi muda dapat mencintai budaya lokal sendiri dan juga tradisi ini sebagai ajang silahturahmi masyarakat Desa Baosan Kidul. Penelitian ini menggunakan metode kualitatif deskriptif yaitu wawancara langsung ke narasumber atau tokoh masyarakat dan hasil wawancara berupa catatan lapangan yang kemudian diambil kesimpulanya yaitu Jamasan memandikan pusaka atau keris menggunakan perasan air jeruk nipis dan biasanya dilakukan disetiap masingmasing rumah pada bulan suro.
\end{abstract}

Kata Kunci: Jamasan Pusaka, Budaya, Pembelajaran Sejarah

\section{Pendahuluan}

Kebendaan atau kebudayaan jasmaniah material culture yang diperlukan oleh manusia untuk menguasai alam sekitarnya, agar kekuatan serta hasilnya dapat diabdikan pada keperluan masyarakat. Cipta merupakan kemampuan mental, kemampuan berpikir dari orangorang yang hidup bermasyarakat dan antara lain menghasilkan filsafat serta ilmu pengetahuan, baik yang berwujud murni, maupun yang telah disusun untuk langsung diamalkan dalam kehidupan sehari-hari.

Rasa dan Karsa dinamakan kebudayaan rohaniah spiritual dan immaterial culture. Dalam konteks ini, hasil rasa masyarakat mewujudkan norma dan nilai kemasyarakatan yang perlu untuk mengadakan tata tertib dalam pergaulan kemasyarakatan. Hal ini dimaksudkan untuk melindungi dari kekuatan yang buruk yang tersembunyi dalam masyarakat.

Hakikatnya penciptaan norma dan kaidah adalah petunjuk tentang bagaimana manusia harus bertindak dan berlaku dalam pergaulan hidup. Oleh karena itu, setiap masyarakat terdapat pola perilaku pattern of behavior. Pola perilaku tersebut adalah cara bertindak atau berkelakuan yang sama daripada orang-orang yang hidup bersama dalam masyarakat yang harus diikuti oleh semua anggota masyarakat tersebut. Pola 
perilakuan masyarakat sangat dipengaruhi oleh kebudayaannya. Jacobus Ranjabar (2013: 29) mengemukakan bahwa kebudayaan adalah hal kompleks yang mencakup pengetahuan, kepercayaan, kesenian, moral, hukum, adat-istiadat dan lain kemampuan serta kebiasaan yang didapat manusia sebagai anggota masyarakat. Dari beberapa pengertian tentang budaya disimpulkan bahwa budaya merupakan pola fikir yang mengatur agar manusia mengerti bagaimana seharusnya bertindak, berbuat, menentukan sikap jika mereka berinteraksi dengan orang lain.

Sebagai cipta kebudayaan adalah dunia khas manusia, kebudayaanlah yang membedakan antara hewan dan manusia. Kegiatan manusia dibiasakan melalalui proses belajar sedangkan hewan melalui proses naluri, dalam kehidupan individu dan sosialnya manusia menggunakan kebudayaan dalam rangka pemenuhan martabat kemanusiaanya. Di dalam kebudayaaan terdapat unsur kesenian yang mana salah satunya yaitu tradisi.

Supardi

(2011:

mengungkapkan bahwa tradisi merupakan pola perilaku yang telah menjadi bagian budaya sejak lama sehingga menjadi adat istiadat dan kepercayaan secara turun temurun. Pelaksanaan tradisi dapat pula diartikan sebagai kegiatan pewarisan kebiasaan dan nilai-nilai. Tradisi menjadi hal yang di yakini dan di percayai keberadaanya oleh masyarakat. Seiring perkembangan peradaban dan kebudayaan manusia, sebagai macam bentuk tradisi pun masih tetap hidup terpelihara serta di jalani oleh masyarakat sampai saat ini. Oleh karena itu, tradisi merupakan salah satu bentuk budaya yang perlu dilestarikan. Melalui pelestarian tradisi, maka generasi penerus dapat mengetahui tujuan, fungsi, makna dan nilai budaya dalam tradisi tersebut. Salah satu tradisi yang masih dilakukan oleh masyarakat desa Baosan Kidul Kecamatan Ngrayun Kabupaten Ponorogo yaitu tradisi jamasan pusaka.

Tradisi Jamasan Pusaka
dilaksanakan karena masyarakat percaya bahwa tradisi tersebut masih memberikan manfaat dalam kehidupan. Jamasan yang artinya memandikan. Keberadaan jamasan pusaka yang masih di dukung sampai saat ini bukan tanpa alasan. Bagi masyarakat Desa Baosan Kidul jamasan pusaka dapat di katakan sebagai tradisi turun temurun atau adat istiadat. Selanjutnya kajian terhadap sebuah tradisi jawa menjadi sesuatu yang menarik untuk di kaji sebagai sumber pembelajaran sejarah.

\section{Tinjauan Pustaka}

\section{A. Kebudayaan}

Menurut Supardi (2011: 102) kebudayaan adalah kumpulan pengetahuan yang secara sosial diwariskan dari generasi ke generasi berikutnya. Kebudayaan memiliki kelemahan dan keunggulan sehingga tidak akan ada suatu kebudayaan 
yang sempurna. Pendapat serupa disampaikan Jacobus Ranjabar (2013: 29), kebudayaan adalah hal kompleks yang mencakup pengetahuan, kepercayaan, kesenian, moral, hukum, adat istiadat dan kemampuan serta kebiasaan yang didapat oleh manusia sebagai anggota masyarakat.

Manusia kemudian menciptakan kebudayaan untuk menjawab masalah tersebut. Berbagai masalah manusia dapat diatasi dengan kebudayaan baik masalah yang rasional maupun masalah yang tidak terjangkau akal manusia. Adapun jenis-jenis kebudayaan salah satunya yaitu tradisi. Supardi (2011: 103) menjelaskan bahwa tradisi merupakan pola perilaku yang telah menjadi bagian budaya sejak lama sehingga maenjadi adat istiadat dan kepercayaan secara turun temurun.

Tradisi merupakan hasil cipta dan karya manusia, objek material, kepercayaan, khayalan, kejadian, atau lembaga yang diwariskan dari generasi ke generasi berikutnya. Misalnya, adat istiadat, kesenian dan properti yang digunakan.

\section{B. Makna Tradisi Jamasan Pusaka}

Tradisi dapat ditunjukkan dari hasil budaya yang masih di temui, baik yang sederhana maupun yang modern. Hal ini merupakan kemajuan pola pikir nenek moyang kita dalam berkaya baik secara fisik maupun non-fisik. Sebagai hasil teknologi, kebudayaan fisik cepat mengalami perkembangan. Kebudayaan sendiri merupakan kumpulan pengetahuan yang secara sosial diwariskan dari generasi berikutnya yang memiliki kelemahan dan keunggulan, oleh karena itu, tidak akan suatu kebudayaan yang sempurna. Tradisi merupakan sistem menyeluruh, terdiri dari cara aspek yang pemberian arti terhadap laku ujaran, laku ritual, dan berbagai jenis laku lainya dari manusia atau sejumlah manusia yang melakukan tindakan satu dengan lainnya (Mursal Esten, 1999: 22).

Tradisi adalah merupakan suatu sistem yang menyeluruh, yang terdiri dari cara aspek yang pemberian arti terhadap laku ujaran, laku ritual dan berbagai jenis laku lainnya dari manusia atau sejumlah manusia yang melakukan tindakan satu dengan lainnya. Tradisi berubah ketika orang memberikan perhatian khusus pada fragmen tradisi tertentu dan mengabaikan fragmen yang lain. Tradisi dapat bertahan dalam jangka waktu tertentu dan tradisi ini dapat hilang bila benda material dibuang dan gagasan ditolak atau dilupakan.

Tradisi muncul dari bawah melalui mekanisme kemunculan secara spontan dan tidak diharapkan serta melibatkan rakyat banyak. Karena sesuatu alasan, individu tertentu menemukan warisan history yang menarik. Perhatian, ketakziman, kecintaan dan kekaguman yang kemudian disebarkan melalui berbagai cara, memengaruhi rakyat banyak. Sikap takzim dan kagum itu berubah menjadi perilaku dalam bentuk upacara, penelitiaan dan pemugaran peninggalan purbakala serta menafsir ulang 
keyakinan lama. Semua perbuatan itu memperkokoh sikap, kekaguman dan tindakan individu menjadi milik bersama dan berubah menjadi fakta sosial sesungguhnya. Jamasan pusaka merupakan salah satu cara merawat benda-benda pusaka seperti keris yang di angggap memiliki tuah. Dalam tradisi masyarakat jawa, jamasan pusaka menjadi sesuatu kegiatan spiritual yang cukup sakral dan dilakukan hanya dalam waktu tertentu saja yaitu di bulan suro.

Merujuk pada KBBI (2008, 562: 1120) Jamasan yaitu mencuci keris, biasanya dilaksanakan setahun sekali pada bulan suro, sedangkan Pusaka yaitu harta benda peninggalan orang yang telah meninggal. Jamasan pusaka mempunyai makna dan tujuan luhur, kegiatan ini termasuk dalam kegiatan ritual budaya yang di nilai sakral. Logam telah digunakan masyarakat sebelum masehi. Logam dapat dibentuk bermacam-macam alat keperluan manusia seperti senjata yaitu: keris, mata panah, tombak, belati dan pedang.

Selanjutnya, tradisi Jamasan pusaka memerlukan berbagai bahan yang tidak sedikit, seperti warangan (sejenis bahan kimia). Warangan berguna membersihkan permukaan besi tosan aji, sekaligus untuk lebih mempertajam pamor benda pusaka. Setelah dipoles dengan warangan, pamor atau guratan estetis batu meteor dan inti baja pada benda pusaka (terutama keris dan mata tombak). Adapun bahan untuk prosesi tradisi Jamasan Pusaka adalah:

1. Bunga setaman terdiri dari 5 macam bunag antara lain bunga mawar merah, mawar putih kanthil, kenanga, melathi.

2. Minyak wangi bahan dasar kayu cendana, atau bunga melathi, atau bahan berbagai bunga misalnya minyak serimpi cap putri duyung.

3. Belimbing wuluh, atau jeruk nipis.

4. Baki atau nampan.

5. Dupa/ratus atau kemenyan.

6. Kain kafan atau kain mori cukup $1 / 2$ meter s/d 1 meter.

7. Tikar dan sikat gigi yang baru (jangan bekas)

\section{Nilai Budaya}

Koentjaraningrat (2009: 153) mengemukakan bahwa nilai budaya merupakan konsep mengenai sesuatu yang ada dalam alam pikiran sebagian besar dari masyarakat yang mereka anggap bernilai, berharga, dan penting dalam hidup sehingga dapat berfungsi sebagai suatu pedoman yang memberi arah dan orientasi pada kehidupan para warga masyarakat tadi. konsep abstrak mengenai masalah besar dan bersifat umum yang sangat penting serta bernilai bagi kehidupan masyarakat.

Nilai budaya itu menjadi acuan tingkah laku sebagian besar anggota masyarakat yang bersangkutan, berada dalam alam pikiran mereka dan sulit untuk diterangkan secara rasional. Nilai budaya bersifat langgeng, tidak mudah berubah 
ataupun tergantikan dengan nilai budaya yang lain, Jamasan Pusaka merupakan tradisi masyarakat jawa merawat bendabenda pusaka, benda bersejarah, termasuk benda-benda yang memiliki tuah atau yang diyakini memiliki kekuatan. Jamasan pusaka juga bisa diartikan mencuci atau memandikan benda pusaka. Pusaka diyakini memiliki kekuatan seperti gong, keris, tombak, kereta pusaka dan berbagai jenis pusaka lainnya.

Jamasan pusaka ini merupakan peristiwa yang sakral dan dilakukan hanya pada waktu tertentu saja. Oleh karena itu terdapat makna dan tujuan luhur yang ditanamkan pada tradisi yang sakral ini. Tradisi jamasan pusaka ini dilakukan pada setiap bulan Suro, karena dalam bulan ini merupakan bulan paling sakral bagi orang Jawa. Orang Jawa harus lebih banyak melakukan mawas diri, evalusasi diri, dan waspada. Kenyataannya dalam bulan suro ini sering terjadi peristiwa yang memberikan makna mendalam.

Tujuan dari tradisi jamasan pusaka adalah tetap mempunyai jalinan rasa ikatan batin, terhadap sejarah dan makna yang ada di balik benda pusaka sehingga jamasan pusaka tidak sekedar membersihkan dan merawat fisik benda pusaka saja, tetapi lebih penting adalah memahami segenap nilai-nilai luhur yang terkandung di dalam benda pusaka. Nilai-nilai luhur yang telah diwariskan ini perlu dihayati dan digunakan dalam kehidupan sehari-hari. Nilai-nilai ini juga menjadi kekayaan khasanah budaya yang meliputi filsafat dan seni dari pemberdayaan budi pekerti. Namun bila dilihat lebih dalam lagi terdapat kebijaksanaan hubungan hidup manusia dengan manusia, manusia dengan alam yang disimbolkan dalam pernik dan detail benda pusaka. Oleh sebab itu, dalam benda pusaka juga menyimpan rangkaian simbol berisi nilai-nilai kearifan lokal. Kearifan sosial yang diinspirasi oleh sifat dan hukum alam di lingkungan masyarakat setempat.

\section{Sumber Pembelajaran Sejarah}

Kochhar (2008: 160) berpendapat bahwa sumber pembelajaran adalah sarana pembelajaran dan pengajaran yang sangat penting, dan istilah history (Sejarah) diambil dari kata historia dalam bahasa Yunani yaitu berarti informasi atau penelitian yang di tujukan untuk memperoleh kebenaran. Tidak perlu memaksakan untuk percaya dengan yang dinamakan pusaka terutama wesi aji. Sebab sebuah kepercayaan tergantung pada perasaan masing-masing manusia.

Akan tetapi, tidak salah seseorang mengetahui dan memahami makna yang terkandung dalam ajaran filsafat para leluhur yang tersimpan dalam bentuk bilahan-bilahan pusaka yang nantinya sebagai salah satu sumber pembelajaran sejarah. Akhir-akhir ini banyak dari kalangan ormas Islam yang mengatakan bid'ah khurofat dalam menyimpulkan pendapat untuk orang yang menyimpan 
pusaka, padahal jika diteliti lebih jauh tidak ada yang menyimpang andai dibahas secara ilmiah. Pengembangan model pembelajaran sejarah juga mempertimbangkan sumbersumber belajar yang efektif, yaitu bahan kajian sejarah (peninggalan dan sumber tertulis tentang sejarah), kemampuan siswa dan guru dalam mengelola kegiatan belajar mengajar. Kemampuan professional guru yang dapat dikembangkan dalam proses pembelajaran adalah menulis, mendramatisasikan, serta kemampuan kreatif lainnya untuk digali.

Pembelajaran sejarah bertujuan untuk peningkatan kesadaran sejarah dengan indikator-indikatornya pemahaman terhadap materi sejarah, penghayatan, perubahan, serta pandangan tentang sejarah. Agar peningkatan kesejarahan dapat tercapai secara maksimal diperlukan beberapa pendekatan dalam pembelajaran sejarah. Tanggung jawab seperti itu harus melibatkan berbagai elemen masyarakat, baik pemerintah maupun akademisi berupa pemberian pemahaman dan pengertian kepada masyarakat akan arti penting dan makna pembelajaran sejarah.

Upaya terkini yang dapat dilakukan melalui perguruan tinggi adalah pemberian pendidikan sosial kepada masyarakat dengan melibatkan sejarawan, antropolog dan sosiolog. Dalam pembelajaran sangat diperlukan adanya pemilihan bentuk model pembelajaran yang berpegang pada hakekat belajar dan pembelajaran, dengan tetap berdasarkan karakteristik ilmu yang akan diajarkan pemilihan model dan metode pembelajaran yang sesuai dengan tujuan kurikulum dan potensi siswa merupakan kemampuan dan keterampilan dasar yang harus dimiliki oleh seorang guru. Hal ini didasari oleh asumsi bahwa ketepatan guru oleh memilih model dan metode. Pembelajaran akan berpengaruh terhadap keberhasilan belajar siswa, karena model dan metode pembelajaran yang digunakan oleh guru berpengaruh terhadap kualitas proses belajar megajar yang dilakukan guru.

Sumber pembelajaran yang dapat digunakan, meliputi: buku cetak, bahan bacaan tambahan, buku latihan, sumber pembelajaran terprogram, sumber referensi umum (seperti ensiklopedia, surat kabar, atlas, pamflet, dan buku-buku terbitan pemerintah), dan buku tambahan untuk bidang studi yang sedang dipelajari.

\section{Metode Penelitian}

Jenis penelitian ini termasuk deskriptif kualitatif. Menurut Usman, dkk (2014: 130) penelitian deskriptif kualitatif diuraikan dengan kata-kata menurut pendapat responden, apa adanya sesuai dengan pertanyaan penelitiannya, kemudian dianalisis pula dengan kata-kata apa yang melatarbelakangi responden berperilaku (berpikir, berperasaan, dan bertindak) seperti itu tidak seperti lainnya, direduksi, di trianggulasi, disimpulkan (diberi makna), dan diverifikasi 
(dikonsultasikan kembali kepada responden dan teman sejawat). Minimal ada tiga hal yang digambarkan dalam penelitian kualitatif, yaitu karakteristik pelaku, kegiatan atau kejadian yang terjadi selama penelitian berlangsung. Alasan pemilihan jenis penelitian ini mengacu pada bahan kajian yaitu studi nilai budaya dan sumber pembelajaran sejarah bagi masyarakat dalam upacara bersih Desa bumi perdikan Desa Baosan Kidul.

Penulis ingin menggambarkan data yang telah diperoleh sehingga dapat menjawab permasalahan yang diteliti. Untuk pengumpulan data dalam penelitian ini dilakukan dengan angket dan dokumentasi. Metode pengumpulan data penelitian ini adalah observasi, wawancara, dan dokumentasi. Dalam mengumpulkan data penelitian ini menggunakan beberapa sumber untuk saling melengkapi data satu dan data lain. Data merupakan salah satu komponen riset, artinya tanpa ada data tidak akan ada riset, karena data yang salah akan menghasilkan informasi yang salah (Husein Umar 2011: 49).

Sumber data dibagi menjadi dua, yaitu: 1). Sumber Data primer merupakan data yang didapat dari sumber pertama baik dari individu atau perseorangan seperti hasil dari wawancara atau hasil dari pengisian kuesioner yang biasa dilakukan oleh peneliti (Husein Umar, 2011: 42). Sumber data primer penelitian ini diperoleh dari wawancara informan, yaitu sesepuh
Desa Baosan Kidul, Dinas Kebudayaan Ponorogo dan masyarakat Desa Baosan Kidul. 2). Sumber Data Sekunder yang merupakan data primer yang telah diolah lebih lanjut dan disajikan baik oleh pihak pengumpul data primer atau oleh pihak lain misalnya dalam bentuk tabel-tabel atau diagram-diagram (Husein Umar, 2011: 42). Data sekunder diperoleh melalui media perantara, dokumen, catatan ataupun laporan yang tersusun dalam arsip kemudian akan dipublikasiakan.

\section{Hasil Dan Pembahasan}

\section{A. Tradisi Jamasan Pusaka}

Jamasan pusaka dikenal sebagai membersihkan atau memandikan wesi aji seperti keris yang berlokasi di Desa Baosan Kidul Kecamatan Ngrayun Kabupaten Ponorogo tepatnya berjarak $42 \mathrm{~km}$ dari arah puat Kota Ponorogo Menuju desa Baosan Kidul. Jamasan Pusaka atau memandikan wesi aji mulai dilaksanakan sejak zaman Kerajaan terutama Kerajaan Majapahit yaitu Pusaka milik raja yang dianggap sakral hingga tradisi jamasan pusaka masih dilaksanakan hingga kini.

Tradisi jamasan pusaka biasa juga dilakukan hampir bersamaan dengan upacara adat atau upacara bersih Desa yang diadakan pada bulan suro jumat legi. Jamasan pusaka diibaratkan seperti ngisahi gaman (memandikan pusaka atau keris) menggunakan perasan air jeruk nipis dan biasanya dilakukan disetiap masing-masing 
rumah pada bulan suro sebab rata-rata setiap rumah memiliki pusaka seperti keris.

Pada prinsipnya jamasan pusaka merupakan salah satu cara merawat bendabenda pusaka seperti keris yang di angggap memiliki tuah. Dalam tradisi masyarakat Jawa, jamasan pusaka menjadi sesuatu kegiatan spiritual yang cukup sakral dan dilakukan hanya dalam waktu tertentu (bulan suro). Oleh karena itu, jamasan pusaka mempunyai makna dan tujuan luhur, kegiatan ini termasuk dalam kegiatan ritual budaya yang di nilai sakral.

\section{B. Nilai Budaya Jamasan Pusaka}

Nilai budaya bersifat langgeng, tidak mudah berubah ataupun tergantikan dengan nilai budaya yang lain. Jamasan Pusaka merupakan tradisi masyarakat Jawa merawat benda pusaka, benda bersejarah, termasuk benda-benda yang memiliki tuah atau yang diyakini memiliki kekuatan. Jamasan pusaka juga bisa diartikan sebagai memandikan benda pusaka. Pusaka diyakini memiliki kekuatan, misalnya gong, keris, tombak, kereta pusaka dan berbagai jenis pusaka lainnya.

Jamasan pusaka ini merupakan peristiwa yang sakral dan dilakukan hanya pada waktu tertentu saja. Oleh karena itu terdapat makna dan tujuan luhur yang ditanamkan pada tradisi yang sakral ini. Tradisi jamasan pusaka ini dilakukan pada setiap bulan Suro, karena dalam bulan ini merupakan bulan paling sakral bagi orang Jawa di mana orang Jawa harus lebih banyak melakukan evalusasi diri. Karena memang kenyataanya dalam bulan suro ini seringkali terjadi peristiwa yang memberikan makna mendalam.

Tujuannya dari tradisi jamasan pusaka adalah tetap mempunyai jalinan rasa ikatan batin, terhadap sejarah dan makna yang ada di balik benda pusaka sehingga tidak sekedar membersihkan dan merawat fisik benda pusaka saja, tetapi lebih penting adalah memahami segenap nilai-nilai luhur yang terkandung di dalam benda pusaka. Nilai-nilai luhur yang telah diwariskan ini perlu dihayati dan digunakan dalam kehidupan sehari-hari.

Nilai budaya dari jamasan pusaka dianggap sesuatu yang abstrak yang dijadikan pedoman serta prinsip dalam bertindak dan bertingkah laku seseorang, karena mempunyai makna didalam tradisi jamasan pusaka, diantaranya adalah

1. Kesan moral yang berkaitan dengan masyarakat yang ditanamkan dalam tradisi jamasan pusaka secara turuntemurun.

2. Nilai konsep hidup dalam pikiran sebagian masyarakat yang meraka anggap begitu mulia.

3. Kedudukan manusia dalam alam hubungan orang dan tentang hal-hal yang diiginkan bertali dengan orang dan lingkungan dan sesama manusia. Jadi artinya dilaksanakan jamasan pusaka mulai zaman dulu dengan adanya 
kesatuan tersebut masyarakat bisa menjalin silahturahmi untuk kerukunan.

4. Nilai budaya dalam jamasan pusaka mengenai yang dianggap penting dan berharga dan tidak menganggap rendah.

Maka dapat disimpulkan bahwa nilai budaya merupakan kedudukan manusia dalam alam hubungan orang dan tentang hal-hal yang diinginkan bertali dengan orang lingkungan dan sesama manusia yang dijadikan pedoman serta prinsip umum dalam bertindak dan bertingkah laku.

\section{Jamasan Pusaka Sebagai Sumber Pembelajaran Sejarah}

Sumber Pembelajaran adalah sarana pembelajaran dan pengajaran yang penting. Sejarah adalah kejadian yang terjadi dimasa lampau yang disusun berdasarkan peninggalan berbagai peristiwa. Sumber pembelajaran Sejarah adalah sarana pembelajaran Sejarah yang sangat penting salah satunya dapat melalui tradisi Jamasan pusaka.

Jamasan pusaka ini dapat dikatakan salah satu warisan budaya dari nenek moyang khususnya di Desa Baosan Kidul. Hal ini bisa dijadikan sebagai sumber pembelajaran Sejarah. Jamasan pusaka salah satu tradisi yang masih dilakukan di Desa Baosan kidul perlu diperkenalkan kepada siswa sebagai generasi penerus di era modernisasi agar tidak tergerus zaman. Hal ini dikarenakan saat ini banyak yang tidak mengenal tradisinya sendiri seperti jamasan pusaka. Di dalam tradisi jamasan pusaka ini yang melakukannya tidak banyak hanya sesepuh Desa saja. Tradisi jamasan pusaka sendiri tidak terlalu banyak tetapi masuk sebagian Sejarah, apalagi berkaitan pula dengan kerajaan jaman dulu.

\section{Penutup}

\section{Simpulan}

Jamasan pusaka merupakan salah satu cara merawat benda-benda pusaka yang diangggap memiliki tuah. Dalam tradisi masyarakat Jawa, jamasan pusaka menjadi kegiatan spiritual yang sakral dan dilakukan dalam waktu tertentu di Bulan Suro seperti di Desa Baosan Kidul Kabupaten Ponorogo. Diperlukan internalisasi tradisi tersebut ke generasi muda supaya dapat mencintai budaya lokal sendiri dan sebagai ajang silaturahmi masyarakat Desa Baosan Kidul. Penggunaan metode kualitatif deskriptif dalam penelitian ini yaitu wawancara narasumber dan tokoh masyarakat, serta hasil wawancara lapangan kemudian diambil kesimpulan bahwa Jamasan memandikan pusaka atau keris menggunakan perasan air jeruk nipis dan biasanya dilakukan setiap rumah masingmasing pada bulan Suro.

\section{Daftar Pustaka}

Departemen Pendidikan Nasional. 2018. Kamus Besar Bahasa Indonesia Pusat Bahasa. Jakarta: Gramedia Pustaka Utama.

Husein Umar. 2011. Metode Penelitian Untuk Skripsi dan Tesis Bisnis. Jakarta: RajaGrafindo Persada 
Jacobus Ranjabar. 2013. Sistem Sosial Budaya Indonesia. Bandung: Alfabeta

Kochhar, S.K. 2008. Pembelajaran Sejarah Teaching of History. Jakarta: PT. Gramedia

Koentjaraningrat. 2009. Pengantar Ilmu Antropologi. Jakarta: Rineka Cipta

Mursal Esten. 1999. Kajian Transformasi Budaya. Bandung: Percetakan Angkasa

Supardi. 2011. Dasar-Dasar Ilmu Sosial. Yokyakarta: Ombak

Usman, dkk. 2014. Metodologi Penelitian Sosial. Jakarta: PT. Bumi Aksara 